\title{
8. CENOZOIC OSTRACODES FROM HOLE 628A, ODP LEG 101, BAHAMAS1
}

\author{
Claude Guernet ${ }^{2}$ and Eric Fourcade ${ }^{2}$
}

\begin{abstract}
The Oligocene to Pliocene section from Hole 628A supplied about 100 species of Tertiary ostracodes. Deep-sea psychrospheric? species (Bradleya cf. dictyon, Agrenocythere cf. gosnoldia, Cardobairdia spp., Henryhowella sp., Cytheropteron spp., etc.) are present throughout the section. Starting in the Miocene, neritic species (Hulingsina sp., Puriana spp., Caudites spp., Loxoconcha fischeri, Cytherelloidea sp., etc.) dominate. Redeposition of these species from the continental shelf seems to be penecontemporaneous with sedimentation. Variations in the assemblages indicate biostratigraphic position. Species having an ecologic or stratigraphic importance are discussed and illustrated.
\end{abstract}

\section{INTRODUCTION}

Five of the sites drilled during Leg 101 penetrated Oligocene (or older) sediments. However, only a small part of the Tertiary series was recovered at two sites (Holes 634A and 635A). Two other Leg 101 holes were difficult to interpret. Hole 627B was difficult because downhole contamination occurred during drilling; Hole $626 \mathrm{D}$, because of downslope contamination by neritic sediments. Therefore, we present only results from Tertiary ostracodes of Hole $628 \mathrm{~A}$.

Hole 628A was located in a water depth of $966 \mathrm{~m}$ north of Little Bahama Bank (latitude $27^{\circ} 31.85^{\prime} \mathrm{N}$; longitude, $78^{\circ} 18.95^{\prime} \mathrm{N}$ ), about $15 \mathrm{~km}$ from the neritic platform (Fig. 1). Today, this platform belongs to the epibathyal zone. Drilling penetrated $298 \mathrm{~m}$ of unconsolidated or slightly lithified sediments and reached the upper Paleocene or the lower Eocene. Ostracodes occur above the base of the lower Oligocene. The lower and middle Miocene are missing from two sections (Austin, Schlager, et al., 1986).

\section{PALEOENVIRONMENTAL INTERPRETATION}

We identified about 100 ostracode species. Those species that occur in at least three samples and are represented by more than five specimens (having carapaces or single valves) are noted in Table 1. Most specimens cannot be assigned precisely to known species because many belong to faunas from deeper-water environments that have not been studied much. However, the specimens can be divided into three ecological groups:

1. Species of genera exclusively or mainly occurring in the modern neritic environment, such as Cytherelloidea, Hulingsina, Jugosocythereis, Puriana, Loxoconcha, and species of other genera with well-developed eye tubercles.

2. Species of genera exclusively or mainly occurring in the modern deep-sea environment (i.e., for some genera this is as shallow as the lower limit of the photic zone). These species include Cardobairdia, Henryhowella, Krithe, Trachyleberidea, Agrenocythere, Poseidonamicus, Bythoceratina, and Pseudocythere.

3. Species belonging to common genera that occur at nearly all depths from the infralittoral or mediolittoral range to the abyssal or bathyal zone, such as Cytherella, numerous Bairdiidea, Echinocythereis, Pterygocythereis.

\footnotetext{
${ }^{\text {I }}$ Austin, J. A., Jr., Schlager, W., et al., 1987. Proc. ODP, Sci. Results, 101: College Station, TX (Ocean Drilling Program)

2 Département de Stratigraphie et UA 319, CNRS, T15, Université Pierre et Marie Curie, 75252 Paris Cedex 05, France.
}

Species of the first two groups are the most interesting for paleobathymetric reconstructions. However, note that (to the limits of our current knowledge of ostracode ecology) it is difficult to discriminate between the infraneritic (circalittoral) zone and the epibathyal one. In fact, below the lower limit of the infralittoral (50-100 m water depth, in clear, well-lighted water), the main zone of biological turnover is the thermocline separating the thermosphere from the psychrosphere. ${ }^{3}$ The depth of the thermocline varies geographically, especially according to latitude, and probably changed during Cenozoic time. Around the Florida-Hatteras slope (the Straits of Florida and the Blake Plateau), the thermocline is a major barrier between shallow- and deep-water species, as shown by Cronin (1983).

In spite of these constraints, this change in ostracode assemblages from Oligocene to late Pliocene (Table 1) allows us to conclude the following:

1. The Oligocene from Hole $628 \mathrm{~A}$ yielded rare ostracodes ( 60 specimens), which belong almost exclusively to common or deep-sea genera, including Cytherella, Krithe, Agrenocythere, Henryhowella, Cardobairdia and "Bairdia," the most typical elements. We interpreted the occurrence of occasional abraded or broken valves of neritic genera (Jugosocythereis, Pokornyella, and Paracytheridea) as transportation of sediment from the continental shelf. This conclusion is also supported by the presence of lepidocycline foraminifers in our samples (Fourcade and Butterlin, this volume).

2. From the middle Miocene (N11 part/N13 part) to the upper Pliocene (the Pleistocene is represented in only one sample, by a single valve of Cytherella), ostracode assemblages contain many specimens and species of genera usually considered neritic, such as Cytherelloidea, Hulingsina, and Puriana (Hazel, 1970; Valentine, 1971; and others). These genera indicate temperate to subtropical marine climates. However, deep-sea genera (such as Agrenocythere, Bradleya, and Bythoceratina) are observed throughout the section. Although not indicated by the specimens that are well preserved and have asimilar sedimentary filling, logic suggests that the valves of neritic taxa were transported from the continental shelf. Since the Miocene, a small part of the infraneritic ostracode population could possibly have colonized the upper part of the continental slope. However, the concomitant presence of bathyal with neritic ostracodes may be attributed to the turbidites that occur in lithologic Unit II of Hole 628A (Austin, Schlager, et al., 1986).

\footnotetext{
${ }^{3}$ For a discussion of these expressions and concepts see Bruun (1957) and Benson (1975a).
} 


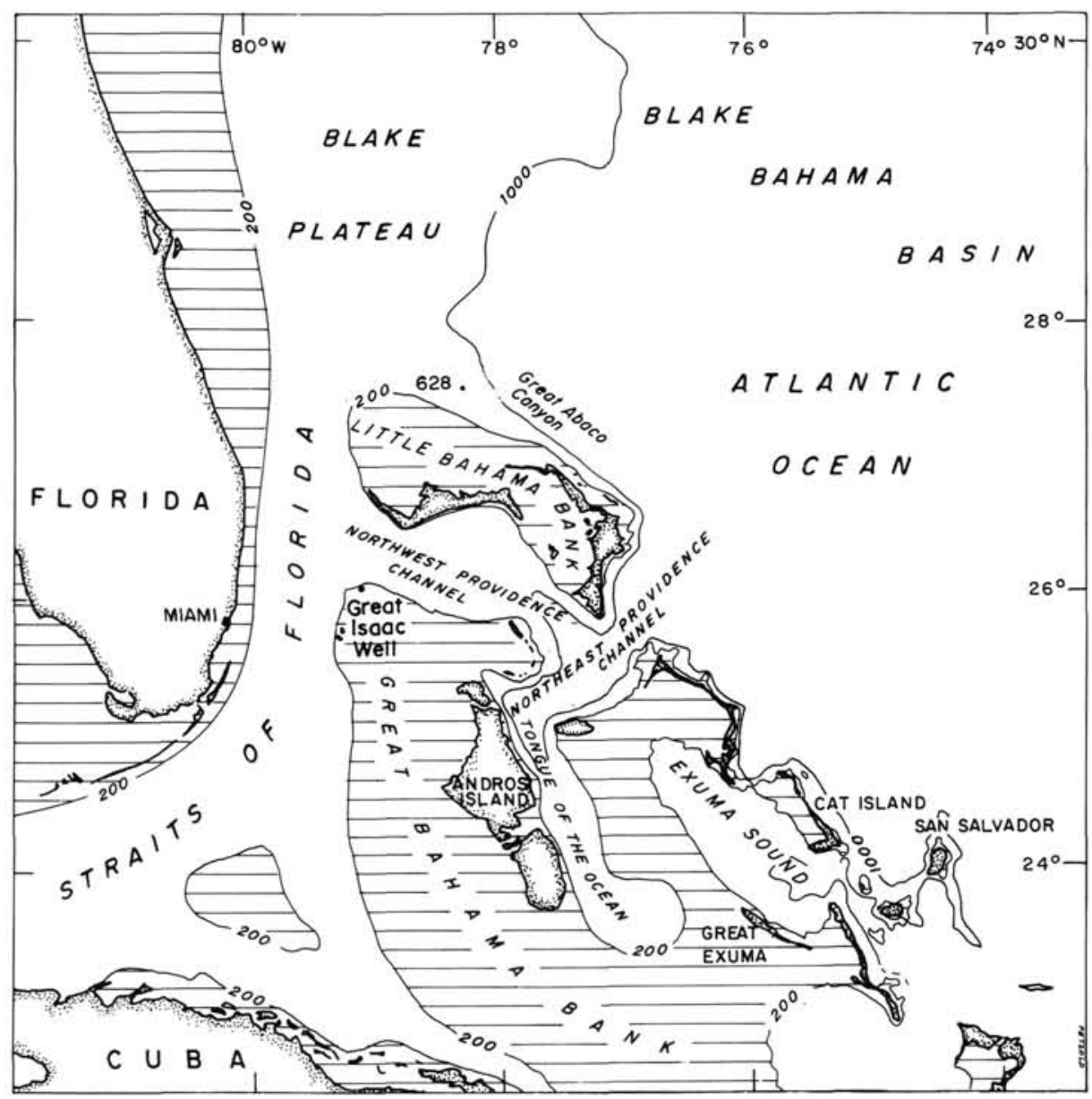

Figure 1. Location map showing Hole 628A from which samples containing Cenozoic ostracodes were studied.

Therefore, it appears that important events took place between the late Oligocene and the late middle Miocene; these events are responsible for the faunal break and the resedimentation of neritic ostracodes on the continental slope. These ostracodes suggest that most of the observed turbidites came from the infralittoral zone. Only those turbidites associated with large benthic foraminifers (Cores 101-628A-11H and 101-628A-12H) probably came from the shallow zones of the ancestral carbonate platform.

The change in specific composition of the ostracode assemblages through time is probably of biostratigraphic importance. The possible redeposition of the continental shelf seems to be penecontemporaneous with specimens indicating off-bank sedimentation. Note that with regard to the Eocene ostracode faunas from DSDP Site 390 (Guernet, 1982) and from Barbados (Steineck et al., 1984) species renewal is complete between the Eocene and the Oligocene, while at the generic level assemblages bear the same psychrospheric features. In contrast, the Oligocene-Miocene transition, despite the early and middle Miocene hiatus at Site 628 , is characterized by the appearance of new species, rather than by extinctions. This "enrichment" continued during the late Miocene and the Pliocene. However, only further studies will enable us to determine if some appearances, such as Hulingsina sp. 1 (Core 101-628A-13H), Gangamocytheridea $\mathrm{cf}$. dictyon, Puriana sp. 1 and Cytherelloidea sp. during the late Miocene (Cores 101-628A-11H and 101-628A-12H), Semicytherura sp. 1, Hulingsina cf. tuberculata, and Ornatoleberis $\mathrm{sp}$. during the Pliocene (Cores 101-628A-8H through 101-628A-4H), which are well-represented in our samples, are biostratigraphically significant.

\section{SYSTEMATIC PALEONTOLOGY}

Among the 100 species observed, many occur as having only one or two valves. Their genetic significance (e.g., reworked specimen or downhole contamination) is particularly suspect. Consequently, these species are neither plotted in Table 1 nor illustrated in Plates 1 through 6. Species having easily identifiable features and ecologic or stratigraphic importance are discussed next. The systematics used here follow Hartmann and Puri (1974).

Order PODOCOPIDA Müller, 1894

Suborder PODOCOPA Sars, 1866

Superfamily CYTHERACEA Baird, 1850

Family CYTHERIDAE Baird, 1850

Genus GANGAMOCYTHERIDEA van den Bold, 1963

Gangamocytheridea cf. dictyon van den Bold, 1963 Pl. 5, Figs. 14 and 15

Remarks. The valves assigned to this species are abundant throughout the Neogene (Table 1) but seem to differ from those described by van den Bold (1963) by their more complex reticulation. G. dictyon, known in the Caribbean in the late Miocene, still lives "on the continental shelf north and east of Trinidad. The maximum depth at which the species has been observed is 30 fathoms" (van den Bold, 1963b). A closely related species, $G$. reticulata (van den Bold, 1957), occurs in the Miocene of Trinidad. 
Table 1. Range chart for Tertiary ostracodes from Hole 628A.

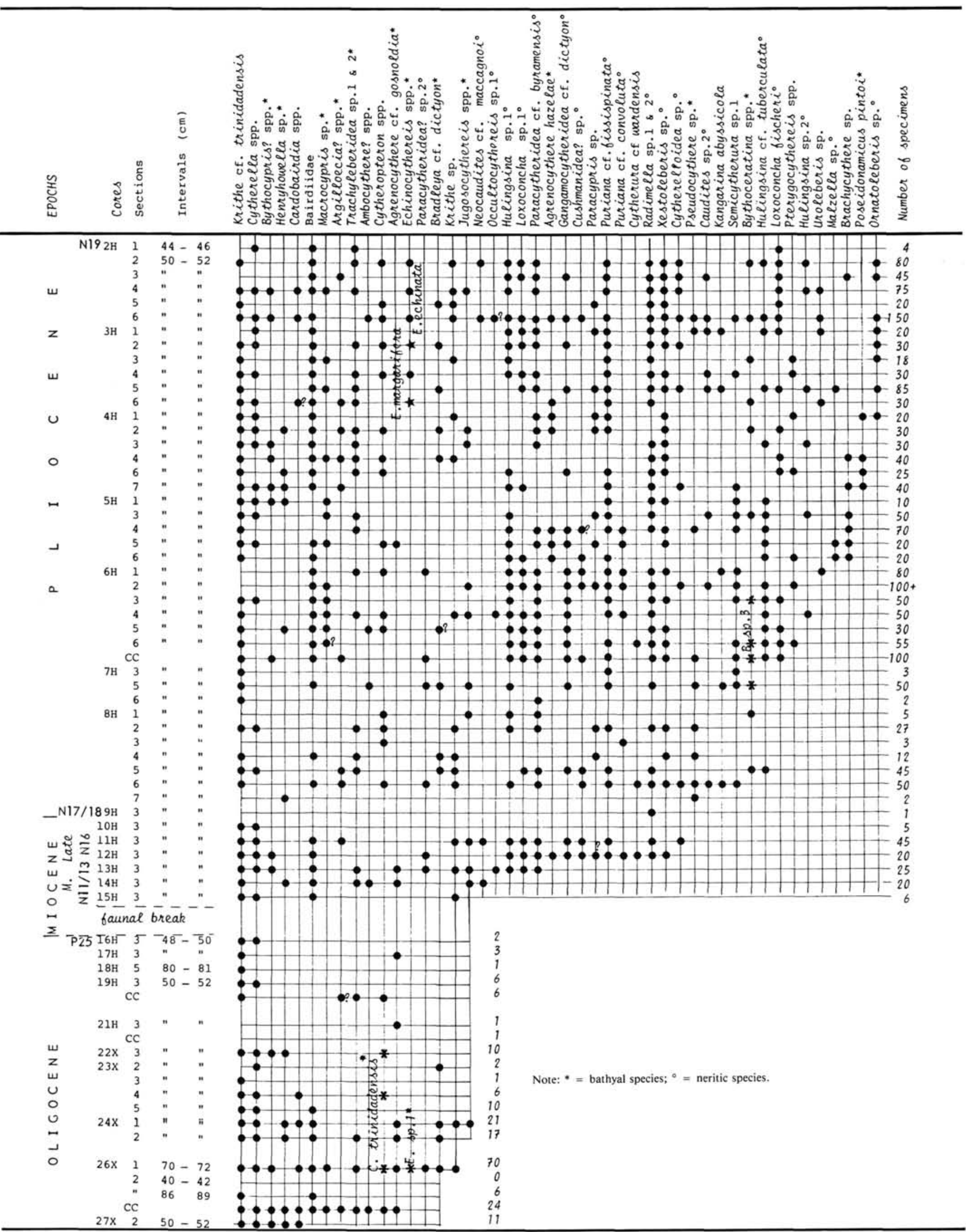




\section{Family CUSHMANIDEIDAE Puri, 1973}

Remarks. The Cushmanideidae are absent in our Oligocene samples but do occur often in the Neogene samples. They are represented by Cushmanidea? sp. (PI. 4, Fig. 8) and particularly by three species ascribed to the genus Hulingsina Puri, 1958: $H$. cf. tuberculata Puri, 1958 (Pl. 4, Fig. 9), $H$. sp. 1 (Pl. 4, Figs. 4 and 6), and $H$. sp. 2. This last species is coarsely punctate and related to $H$. wilberti (Puri, 1952). It occurs sporadically in the Pliocene samples. The known species of the genera Cushmanidea and Hulingsina are all neritic, and the genus $\mathrm{Hu}$ lingsina seems to indicate warm temperate to subtropical climates (Hazel, 1970; Valentine, 1971).

Description. Hulingsina have a contraction of the posterior end of the carapace and an individualization (on one of the valves) of a kind of caudal process, which corresponds internally to a notch. The species may be a useful criterion for distinguishing Hulingsina from Cushmanidea and related genera (see Athersuch, 1982).

Family KRITHIDAE Mandelstam, 1960

Genus KRITHE Brady, Crosskey and Robertson, 1874

The genus Krithe is represented in all Cenozoic sediments from Hole $628 \mathrm{~A}$ by at least two species.

Krithe cf. trinidadensis van den Bold, 1958

$$
\text { Pl. 1, Figs. } 8 \text { and } 11
$$

Description. Valves from Hole 628A present the following features, described by van den Bold for Oligocene and Miocene Krithe from Trinidad, that is, strong sexual dimorphism, anterodorsal inflection, posterior dorsal margin bent, and narrow vestibulum; however, Hole $628 \mathrm{~A}$ specimens are more elongated (for size of the valves see Pl. 1, R.V. + . $\mathrm{L}=0.9 \mathrm{~mm}, \mathrm{~h}=0.5 \mathrm{~mm}$; R.V. $\left.\sigma^{7}, \mathrm{~L}=1.1 \mathrm{~mm}, \mathrm{~h}=0.49 \mathrm{~mm}\right)$.

Remarks. $K$. trinidadensis is a common species in deep-sea, middle Eocene and Oligocene deposits on Barbados (Steineck et al., 1984). It is probably pro-parte conspecific of Krithe sp. D of Peypouquet (1979) and particularly of Krithe sp. D12 of the Pliocene-Quaternary of DSDP Site 517 (Benson and Peypouquet, 1983). K. trinidadensis is similar to K. morkhoveni van den Bold, 1960, from the Miocene of Trinidad, but this latter species has a less sinuous inner lamella.

\section{Krithe cf. hiwanneensis Howe and Law 1936}

$$
\text { (Pl. 1, Figs. 14-15) }
$$

Remarks. The valves of this species are less common than those of the one previously described. They are tentatively assigned to $K$. hiwanneensis, which occurs in deep-sea Paleogene deposits from Barbados. Those found in Hole 628A, however, do not have a large vestibulum like the specimen illustrated by Steineck et al. (1984). Indeed, all the Krithe found in the Cenozoic of Hole $628 \mathrm{~A}$ as well as those from the Oceanic Formation of Barbados have a constricted vestibulum. According to Peypouquet (1979), this feature corresponds to well-oxygenated waters. In general, the relative abundance of Krithe in our samples, particularly those from the Oligocene section, signified deep-water environments (Neale, 1985).

\section{Families TRACHYLEBERIDIDAE Sylvester-Bradely, 1958 and HEMICYTHERIDAE Puri, 1953}

Remarks. These families were not distinguished because of our difficulty in observing the internal features of the valves from Hole 628A.

\section{Genus PURIANA Coryell and Fields, 1937}

Remarks. Species attributed to Puriana are present in all Neogene sediments from Hole 628A. Two to five valves were recovered in most of the samples. Currently, the genus Puriana is represented by neritic and probably thermophilic species. However, Valentine (1971) reported the genus from modern assemblages occurring as deep as $\sim 140 \mathrm{~m}$ offshore southern Virginia.

\section{Puriana? cf. fissispinata Benson and Coleman, 1963}

$$
\text { Pl. 5, Figs. } 1 \text { and } 2
$$

Description. The crests of these valves are narrower than those of $P$. convoluta Teeter, 1975 (see figure in Cronin and Hazel, 1979; Hazel, $1977,1983)$. Their arrangement is also slightly different, and their valves are slimmer. They are probably instars of $P$. fissispinata, species that must perhaps be assigned to Cornuquimba Ohmert, 1968 (after T. M. Cronin, pers. comm., 1987). Puriana? cf. fissispinata is present in Core $101-628 \mathrm{~A}-12 \mathrm{H}$ (i.e., as young as the late Miocene).

\section{Genus AGRENOCYTHERE Benson, 1972 \\ Agrenocythere cf. gosnoldia Benson, 1972 \\ Pl. 2, Figs. 3 and 4}

Remarks. Specimens from Hole 628A were differentiated from the Eocene species described by Benson (1972) by their elongated shape and details of their ornamentation. Valves of different instars and of different sexes were compared because each sample contains only one to three valves (except Sample 101-628A-26X-1, 70-72 cm, from which we extracted 10 or 11 valves corresponding to at least four molts).

\section{Agrenocythere cf. hazelae (van den Bold), 1946}

$$
\text { Pl. 2, Fig. } 7
$$

Description. Valves from Hole 628A are represented by early instars and are characterized by the division of their pore-conuli (especially on the occular ridge and on the dorsal spines). The caudal process is short and may be a larval feature.

Remarks. A. hazelae was described first from the lower Miocene of Cuba. The species still lives in the Carribean area and in the eastern Pacific (Benson, 1972). We observed it only in the Neogene of Hole 628A.

$$
\begin{gathered}
\text { Genus BRADLEYA Hornibrook, } 1952 \\
\text { Bradleya dictyon (Brady, 1880) } \\
\text { Pl. 2, Fig. } 6
\end{gathered}
$$

Remarks. This species is known in the Atlantic and the Southern Hemisphere from the lower Miocene to Holocene. It occurs sporadically in the Neogene from Hole 628A (Table 1). The Oligocene at this site contains several valves belonging to a new subspecies, or possibly a different species, that is similar, in its coarser reticulation, to Bradleya johnsoni Benson (in Benson and Peypouquet, 1983) of the lower Miocene from the South Atlantic.

The genera Agrenocythere, Bradleya, Poseidonamicus (P. pintoi, Pl. 3, Fig. 13), and Trachyleberidea are among the more characteristic of deep-water taxa. They are associated with widespread genera (Krithe and Cytherella) in the Oligocene from Hole 628A and are less numerous in the middle Miocene with respect to neritic genera.

\section{Genus ECHINOCYTHEREIS Puri, 1952} cles.

Three species are ascribed to this genus. Only one bears eye tuber-

$$
\text { Echinocythereis margaritifera (Brady, 1870) }
$$

$$
\text { Pl. 6, Fig. } 3
$$

Description. In a lateral view, the valves appear subquadrangular, with large pore-conuli and well-developed eye tubercles (perhaps an adaptation to a life in a shaded environment).

Remarks. Today, this tropical to cold temperate species is known from the shelf and upper slope of the Gulf of Mexico and Florida and from off Cape Hatteras down to a depth of $2000 \mathrm{~m}$ (Hazel, 1970).

\section{Echinocythereis echinata (Sars, 1866)}

$$
\text { Pl. 6, Fig. } 1
$$

Remarks. Valves from Hole 628A can be identified with Sars' species as illustrated by Benson et al. (1983). Today E. echinata seems to be a blind species, living in the cold, deep water of the Atlantic Ocean. Its valves and carapaces occur at depths greater than $3000 \mathrm{~m}$. Its occurrence with $E$. margaritifera in the Pliocene from Hole 628A (unless it results from postmortem reworking) points out an epi- or mesobathyal environment and a temperature of about $10^{\circ} \mathrm{C}$.

\section{Echinocythereis sp. 1}

$$
\text { Pl. 2, Fig. } 2
$$

Description. This species also lacks well-developed eye tubercles and is similar to $E$. echinata in the pore-conuli arrangement, although these specimens are much larger, except in the anterior, where they disappear. Their valves are more quadrangular than those of $E$. echinata, of which $E$. sp. 1 might be an ancestral form. They occur in only one of the Oligocene samples (Table 1) from Hole 628A. 
Genus NEOCAUDITES Puri, 1960

Neocaudites aff. maccagnoi (Ciampo, 1971)

$$
\text { Pl. 4, Fig. } 7
$$

This neritic species, represented by a few valves in Neogene sediments from Hole 628A (Plate 1), is shorter than N. maccagnoi (see Bonaduce et al., 1980) from the Pleistocene or Holocene of the Mediterranean and Red seas, where the species is assigned to genus Falsocythere (Ruggieri, 1972). T. M. Cronin (pers. comm., 1987) discovered a species much like $N$. aff. maccagnoi in the western Pacific.

\section{Family LOXOCONCHIDAE Sars, 1825 Genus LOXOCONCHA Sars, 1866 \\ Loxoconcha fischeri (Brady, 1869)

$$
\text { Pl. 5, Fig. } 5
$$

Description. This species is distinguished by its general shape, its well-defined anteriodorsal angle, an anterior margin vertically "truncated," and its reticulation. Two ridges are developed anteriorly in a "V" shape. The species has posteriodorsal and posterioventral nodes.

Remarks. In the study area, $L$. fischeri occurs from the Miocene to the Holocene (van den Bold, 1957, 1963, 1966, 1969; Howe and van den Bold, 1975). Although never abundant (generally one or two valves occur), it is the most frequent Loxoconcha in the Pliocene of Hole 628A (Table 1).

\section{Family PARACYTHERIDEIDAE Puri, 1957 \\ Genus PARACYTHERIDEA Müller, 1894}

Paracytheridea aff. byramensis Howe and Law, 1936 Pl. 6, Figs. 5 and 6

Remarks. By their carapace size, their proportion, and their ornamentation, valves from Hole 628A appear related to $P$. byramensis from the Oligocene of Mississippi (see Plate 10, Fig. 3 of Hazel et al., 1980). Hole 628A specimens lack eye tubercles and can be distinguished from $P$. byramensis by their less prominent anteriodorsal region. Probably, they are conspecific of $P$. sp. A of Colon Harbour (Panama) illustrated by van den Bold (1966). P. aff. byramensis is one of the Neogene species found most often in Hole 628A.

Family CYTHERURIDAE Müller, 1894

Genus SEMICYTHERURA Wagner, 1957

\section{Semicytherura sp. 1 \\ Pl. 5, Figs. 9 and 11}

Remarks. This species is probably similar to Semicytherura sp. B of Hazel et al. (1980), mentioned as S. byramensis in the Glendon Formation (Oligocene) of Mississippi and Alabama; however, its caudal process is more triangular. It is similar to Cytherura sp. A from the Pleistocene of Virginia (Valentine, 1971). Beyond its general shape, S. sp. 1 is characterized by its ornamentation, including ventrolateral ridges and sockets settled in the mesh of the reticulum.

\section{Family XESTOLEBERIDIDAE Sars, 1828 Genus ORNATOLEBERIS Keij, 1975 \\ Ornatoleberis sp. \\ PI. 6, Fig. 9}

Description. This species is rare in the Pliocene of Hole 628A; however the species is interesting because of its similarity to $O$. fortii Bonaduce et al. (1980), which lives in the Red Sea to a depth of $25 \mathrm{~m}$. Ornamentation and ventrolateral nodosity are similar, but the caudal appendix is better marked here.

Remarks. According to T. M. Cronin (pers. comm., 1987), $O$. aff. fortii also commonly occurs in the western Pacific. Has this species penetrated into the western Atlantic from the Mediterranean by way of the eastern Atlantic during the Neogene or from the Pacific (with $N$. aff. maccagnoi) through the Panamanian seaway?

\section{SUMMARY AND CONCLUSIONS}

The Tertiary of Hole 628A yielded about 100 species of ostracodes. Only those occurring in several samples were mentioned in Table 1 and illustrated in Plates 1 through 6.

We reached the following conclusions from our study:
1. During the Oligocene (Cores 101-628A-27X through 101$628 \mathrm{~A}-16 \mathrm{H}$ ) deep-sea or common species prevail, whereas from the middle Miocene onward (unfortunately, the lower Miocene is absent in Hole 628A), neritic species that were transported downslope from the continental shelf are more numerous. This change perhaps is the result of a late Oligocene-early Miocene eustatic event and/or of the progradation of the carbonate platform (Austin, Schlager, et al., 1986).

2. During the Neogene (Cores 101-628A-15H through 101$628 \mathrm{~A}-2 \mathrm{H})$, specific diversity increases. Most likely this change has biostratigraphic significance; however, it must be confirmed and documented by future investigations.

\section{ACKNOWLEDGMENTS}

We thank J. Austin, A. Palmer, W. Schlager, T. Cronin, and J. Hazel for their critical reading of this manuscript and for valuable suggestions for its improvement. We thank G. Bonaduce for documentation about Ornatoleberis. We also thank ODP for the opportunity to study Ostracodes of Leg 101. This study was funded by grants from CNRS ATP and supported by ODP France.

\section{REFERENCES}

Athersuch, J., 1982. Some ostracode genera formerly of the family Cytherideidae Sars. In Bate, R. H., Robinson, E., Sheppard, L. M. (Eds.), Fossil and Recent Ostracods: 231-275.

Austin, J. A., Schlager, W., et al., 1986. Site 628: Little Bahama Bank. Proc. ODP, Init. Repts., 101: College Station, TX (Ocean Drilling Program), 213-270.

Benson, R. H., 1972. The Bradleya problem, with descriptions of two new psychrospheric ostracode genera, Agrenocythere and Poseidonamicus (Ostracode:Crustacea). Smithson. Contrib. Paleobiol., 12:1137.

1975a. The origin of the psychrosphere as recorded in changes of deep sea ostracode assemblage. Lethaia, 8:69-83.

1975b. The paleoecology of the ostracodes of DSDP Leg 42A. In Hsü, K., Montadert, L., et al., Init. Repts. DSDP, 42, Pt. 1: Washington (U.S. Govt. Printing Office), 777-787.

1983. Biomechanical stability and sudden change in the evolution of the deep-sea ostracode Poseidonamicus. Paleobiology, 9: 398-413.

Benson, R. H., and Coleman, G. L., 1963. Recent marine ostracodes from the eastern Gulf of Mexico. Univ. Kansas Paleontol. Contrib., 2:1-52.

Benson, R. H., DelGrosso, R. M., and Steineck, P. L., 1983. Ostracode distribution and biofacies, Newfoundland continental slope and rise. Micropaleontology, 29:430-453.

Benson, R. H., and Peypouquet, J. P., 1983. The upper and mid-bathyal Cenozoic ostracode faunas of the Rio Grande Rise found on Leg 72, Deep Sea Drilling Project. In Barker, P. F., Carlson, R. L., Johnson, D. A., et al., Init. Repts. DSDP, 72: Washington (U.S. Govt. Printing Office), 805-818.

Bonaduce, G., Masoli, M., Minichelli, G., and Pugliese, N., 1980. Some new benthic marine ostracode species from the Gulf of Aqaba (Red Sea). Boll. Soc. Paleontol. Ital., 19:143-178.

Breman, E., 1976. The distribution of ostracodes in the bottom sediments of the Adriatic Sea. Vrije Univers. Amsterdam Public., sp.n.: $1-165$.

Bruun, A. F., 1957. Deep sea and abyssal depths. Geol. Soc. Am. Mem., 67:641-672.

Cronin, T. M., 1983. Bathyal ostracodes from the Florida-Hatteras slope, the Straits of Florida and the Blake Plateau. Mar. Micropaleontol., 8:89-119.

Cronin, T. M., and Hazel, J. E., 1979. Ostracode biostratigraphy of Pliocene and Pleistocene deposits of the Cape Fear Arch Region, North and South Carolina. U.S. Geol. Surv. Prof. Pap., 1125-B:1-24.

Ducasse, O., 1981. Étude populationniste du genre Cytherella (Ostracodes) dans les facies bathyaux du Paléogène aquitain. Bull. Inst. Géol. Bassin d'Aquitaine, 30:161-186.

Grossman, S., and Benson, R. H., 1967. Ecology of Rhizopodea and Ostracoda of southern Pamlico Sound Region, North Carolina. Univ. Kansas Paleontol. Contrib., 44:1-90. 
Guernet, C., 1982. Contribution à l'étude des faunes abyssales: les ostracodes paléogènes du bassin des Bahamas, Atlantique Nord (DSDP, Leg 44). Rev. Micropaléontol., 25:40-56.

Hartmann, G., and Puri, H. S., 1974. Summary of neontological and paleontological classification of Ostracoda. Mitt. Hamburg. Zool. Mus. Inst., 70:7-73.

Hazel, J. E., 1967. Classification and distribution of the Recent Hemicytheridea and Trachyleberididae (Ostracoda) off northwestern North America. U.S. Geol. Surv. Prof. Pap., 564:1-49. , 1970. Ostracode zoogeography in the southern Nova Scotian and northern Virginian faunal provinces. U.S. Geol. Surv. Prof. Pap., 529-E:1-21.

1977. Distribution of some biostratigraphically diagnostic ostracodes in the Pliocene and lower Pleistocene of Virginia and northern North Carolina. J. Res. U.S. Geol. Surv., 5:373-388. 1983. Geology and paleontology of the Lee Creek Mine, North Carolina, Part I. Smithson. Contrib. Paleobiol., 53:81-199.

Hazel, J. E., Mumma, M. D., and Huff, W. J., 1980. Ostracode biostratigraphy of the lower Oligocene of Mississippi and Alabama. Trans. Gulf Coast Assoc, Geol. Soc., 30:361-401.

Howe, H. V., and van den Bold, W. A., 1975. Mudlump Ostracoda. Bull. Am. Paleontol., 65:303-315.

Howe, H. V., and Law J., 1936. Louisiana Vicksburg Oligocene Ostracoda. Louisiana Geol. Surv. Bull., 7:1-96.

Keij, A. J., 1975. Note on three Holocene Indo-Malaysian ostracode species. Koninkl. Nederl. akad. van Wetens., Amsterdam, 78:231241.

Neale, J. W., 1985. The incidence and distribution of Cladocopine, Platycopine and Podocopine Ostracoda in certain biogas and incal samples taken from deeper waters of the N.E. Atlantic. In Laubier, L., and Monniot, C. (Eds.), Peuplements profonds du golfe de Gascogne: Paris (IFREMER), 413-417.

Peypouquet, J. P., 1979. Ostracodes et paléoenvironnement:méthodologie et application aux domaines profonds du Cénozoique. Bull. B.R.G.M., 2,4(1):3-79.

Puri, H. S., 1952. Ostracode genus Cytherideis and its allies. J. Paleontol., 26:199-212.

Puri, H. S., and Vanstrum, V. V., 1971. Stratigraphy and paleoecology of the Late Cenozoic sediments of South Florida. Bull. Centre Rech. Pau-SNPA, 5:433-448.

Ruggieri, G., 1972. Su alcuni Ostracodi marini plio-pleistoceni mediterranei. Atti Soc. It. Sc. Nat. e Museo Civ. St. Nat. Milano, 113:89113.

Steineck, P. L., 1981. Upper Eocene to middle Miocene ostracode faunas and paleo-oceanography of the north coastal belt, Jamaica, West Indies. Mar. Micropaleontol., 6:339-366.

Steineck, P. L., Breen, M., Nevins, N., and O'Hara, P., 1984. Middle Eocene and Oligocene deep-sea Ostracoda from the Oceanic Formation, Barbados. J. Paleontol., 58:1463-1496.

Teeter, J. W., 1975. Distribution of Holocene marine Ostracoda from Belize. AAPG Bull., 2:458-459.

Valentine, P. C., 1971. Climatic implication of a late Pleistocene ostracode assemblage from southeastern Virginia. U.S. Geol. Surv. Prof. Pap., 683-D:1-28.

van den Bold, W. A., 1946. Contribution to the study of Ostracoda with special reference to the Tertiary and Cretaceous microfauna of the Caribbean region [Ph.D. dissert.]. Univ. Utrecht, The Netherlands. , 1957. Oligo-Miocene Ostracoda from southern Trinidad. Micropaleontology, 3:231-254.

1958. Ostracoda of the Brasso Formation of Trinidad. Micropaleontology, 4:391-418.

, 1960. Eocene and Oligocene Ostracoda of Trinidad. Micropaleontology, 6:145-196.

1963a. The ostracode genus Orionina and its species. J. Paleontol., 37:33-50.

1963b. Upper Miocene and Pliocene Ostracoda of Trinidad. Micropaleontology, 9:361-424. 6:43-64. 1966. Ostracoda from Colon Harbour, Panama. Carib. J. Sci., 1969. Neogene Ostracoda from southern Puerto Rico. Carib. J. Sci., 9:117-133.

, 1974. Taxonomic status of Cardobairdia (van den Bold, 1960) and Abyssocypris n. gen.; two deepwater ostracode genera of the Caribbean Tertiary. Geoscience and Man, 6:65-79.
1981. Distribution of Ostracoda in the Neogene of central Haiti. Bull. Am. Paleontol., 79(312):1-136.

Date of initial receipt: 27 August 1986

Date of acceptance: 30 June 1987

Ms 101B-123

\section{APPENDIX \\ Systematic Listing of Cenozoic Species Hole 628A}

Cytherella sp. 1

Cytherella sp. 2 gr. consueta Deltel, 1961 (see Ducasse, 1981)

Cytherella sp. 3

Cytherelloidea sp.

Cardobairdia

C. gr. ovata van den Bold, 1960: Sections 101-628A-27X-2, 101628A-26X-CC, and 101-628A-24X-1.

C. gr. asymmetrica (van den Bold, 1946): Section 101-628A-26X-1. Paranesidea? sp. 1 and sp. 2.

Paranesidea cf. cassida (van den Bold, 1946) (see also Steineck, 1981); Section 101-628A-23X-5.

Neonesidea? sp.

Triebelina coronata (Brady, 1870); Section 101-628A-2H-4.

Bythocypris spp.

Gangamocytheridea cf. dictyon van den Bold, 1963a.

Eucythere sp.; Sections 101-628A-8H-5, 101-628A-8H-1, and 101-628A$7 \mathrm{H}-5$.

Cushmanidea sp.

Hulingsina cf. tuberculata Puri, 1958.

Hulingsina sp. 1

Hulingsina sp. 2; Sections 101-628A-6H-6, 101-628A-5H-3, and 101$628 \mathrm{~A}-2 \mathrm{H}-2$.

Krithe cf. trinidadensis van den Bold, 1958.

Krithe cf. hiwanneensis Howe and Law, 1936 (see also Steineck et al., 1984).

Parakrithe sp.; Section 101-628A-1H-3.

Puriana cf. convoluta Teeter, 1975 (see also Hazel, 1983).

Puriana cf. fissispinata Benson and Coleman, 1963.

Trachyleberidea cf. blanpiedi Howe and Law, 1936.

Trachyleberidea cf. mammidentata van den Bold, 1981; Sections 101$628 \mathrm{~A}-3 \mathrm{H}-5$ and $101-628 \mathrm{~A}-3 \mathrm{H}-6$.

Agrenocythere gr. gosnoldia Benson, 1972.

Agrenocythere cf. hazelae (van den Bold, 1946) (see also van den Bold, 1957; Benson, 1972).

Pterygocythereis aff. americana Ulrich and Bassler, 1904 in Howe and van den Bold, 1975; Sections 101-628A-6H-2, 101-628A-3H-3 and 101-628A-3H-4.

Pterygocythereis sp. 2 = P. sp. 2 Howe and van den Bold, 1975; Sections $101-628 \mathrm{~A}-6 \mathrm{H}-2$ and $101-628 \mathrm{~A}-3 \mathrm{H}-4$.

Pterygocythereis sp.

Brachycythere sp.

Echinocythereis echinata (Sars, 1866).

Echinocythereis sp. I gr. echinata

Echinocythereis margaritifera (Brady, 1870) (see also Hazel, 1967, 1970).

Henryhowella sp.

Ambocythere spp.

Radimella sp. 1.

Radimella sp. 2.

Malzella sp.

Bradleya dictyon (Brady, 1880).

Poseidonamicus pintoi Benson, 1972.

Jugosocythereis spp. gr. pannosa (Brady, 1869).

Orionina sp.; Sections 101-628A-13H-3 and 101-628A-6H-1.

Caudites sp. 1; Sections 101-628A-13H-3 and 101-628A-8H-2.

Occultocythereis sp. 1

Neocaudites aff. maccagnoi (Ciampo, 1971) (see also Bonaduce et al., 1970).

Loxoconcha sp. 1

Loxoconcha fischeri (Brady, 1869).

Loxoconcha aff. rugosa van den Bold, 1946; Sections 101-628A-8H-5 and $101-628 \mathrm{~A}-12 \mathrm{H}-03$.

Paracytheridea aff. byramensis Howe and Law, 1936 (see also Hazel et al., 1980). 
Paracytheridea sp. 1; Sections 101-628A-26X-2 and 101-628A-8H-6.

Paracytheridea sp. 2.

Cytherura cf. wardensis Howe and Brown, 1935 (in Valentine, 1974).

Cytherura cf. hermesi van den Bold, 1946; Sections 101-628A-8H-3 and 101-628A-6H-CC.

Hemicytherura sp.; Sections 101-628A-4H-4 and 101-628A-6H,CC.

Kangarina abyssicola (Müller, 1894) (see also Breman, 1976, van den Bold, 1963a, etc.)

Semicytherura sp. 1.

Cytheropteron trinidadensis van den Bold, $1960=$ Pelecocythere trinidadensis (Pl. 1, Fig. 13).
Cytheropteron spp.

Xestoleberis sp.

Uroleberis sp.

Ornatoleberis sp.

Bythoceratina spp.

Pseudocythere sp.

Pellucistoma aff. spurium van den Bold, 1963a; Section 101-628A-11H-3. Macrocypris sp.

Paracypris sp.

Argilloecia spp. 
C. GUERNET, E. FOURCADE

\section{PLATES 1 THROUGH 6}

All the illustrated valves or carapaces come from Hole 628A and, except for PI. 2, Figs. 2 and 4 , from intervals $50-52 \mathrm{~cm}$; sections only are then indicated.

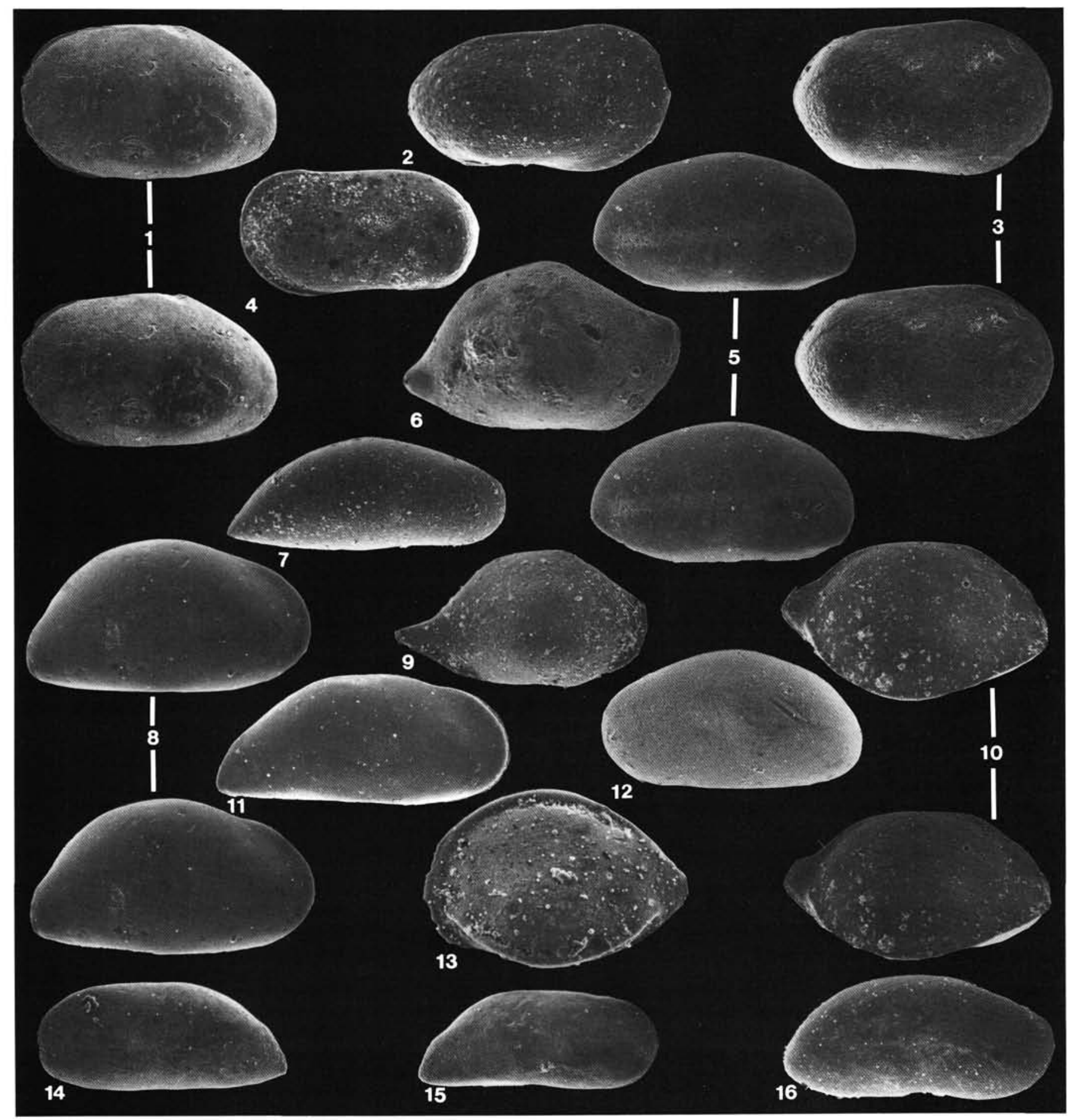

Plate 1. Oligocene ostracodes of Hole 628A, species belonging to common genera. 1. Cytherella sp. 2 gr. consueta, L.V. $\times 47$, Section 101-628A24X-2. 2-3. Cytherella sp. 1, R.V. $\times 63$, Section 101-628A-27X-2. 4. Cytherella sp. 3, L.V. $\times 55$, Section 101-628A-19H-3. 5. Cardobairdia gr. ovata, R.V. $\times 75$, Section 101-628A-24X-1. 6. Paranesidea? sp. 1, R.V. $\times 45$, Section 101-628A-24X-2. 7. Macrocypris sp., R.V. $\times 40$, Section 101-628A-26X, CC. 8 and 11. Krithe cf. trinidadensis, R.V. $q \times 53$, Section 101-628A-23X-4 and R.V. $\delta \times 46$, Section 101-628A-23X-4. 9. Paranesidea cf. cassida, R.V. (larv.?) $\times 62$, Section 101-628A-23X-5. 10. "Cytheropteron" sp. 2, R.V. $\times 60$, Section 101-628A-26X, CC. 12. Bythocypris? sp., L.V. $\times 40$, Section 101-628A-17H-3. 13. Pelecocythere trinidadensis L.V. $\times 110$, Section 101-628A-22X-3. 14-15. Krithe cf. hiwanneensis, L. and R.V. $\left(\sigma^{\prime}\right.$ ?) $\times 53$, Section 101-628A-24X-1. 16. Bythocypris? sp., R.V. $\times 48$, Section 101-628A-27X-2. 


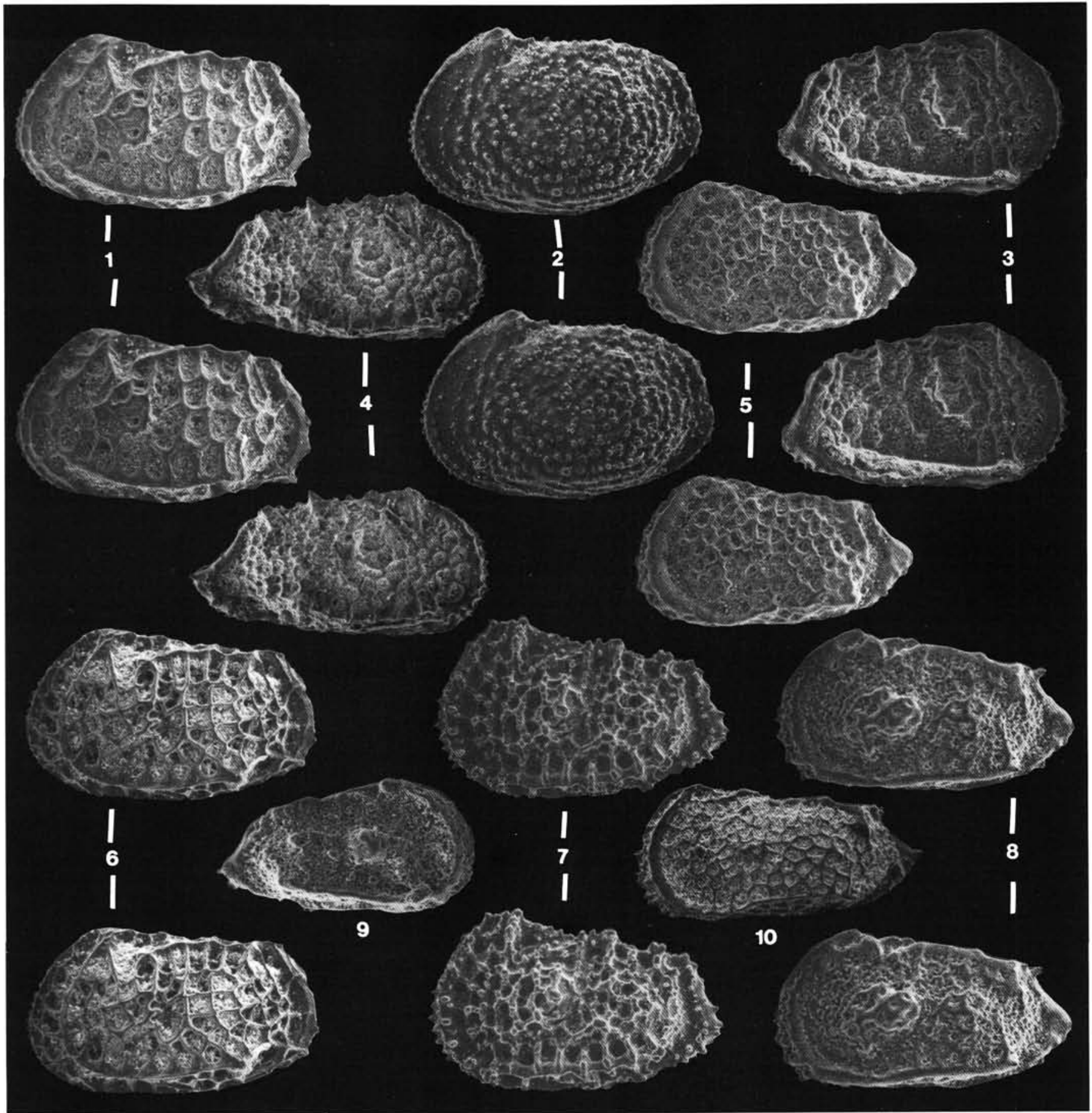

Plate 2. Cenozoic ostracodes (Trachyleberididae or Hemicytherididae) of Hole 628A, probably deep-sea species. 1. Bradleya cf. dictyon, LV. ( $\$$ ?) $\times 53$, Section 101-628A-24X-2. 2. Echinocythereis sp. 1, R.V. $\times 50$, Sample 101-628A-26X-1, 70-72 cm. 3-4. Agrenocythere cf. gosnoldia, larval R.V. $\times 63$, Section 101-628-24X-2 and adult(?) R.V. $\times 35$, Sample 101-628A-26X-1, 70-72 cm. 5. Trachyleberidea sp. 1, L.V. ( $\$$ ) $\times 55$, Section 101-628A-24H-2. 6. Bradleya dictyon, L.V. ( 9 ?), $\times 50$, Section 101-628A-8H-4. 7. Agrenocythere hazelae, L.V. $\times 55$, Section 101-628A-2H-6. 8. "Trachyleberidea" mammidentata, L.V. $\times 65$, Section 101-628A-3H-6. 9. Trachyleberidea cf. blanpiedi, R.V. $\times 70$, Section 101-628A-13H-3. 10. Trachyleberidea sp. 1, L.V. $\left(\sigma^{\prime}\right.$ ?) $\times 55$, Section 101-628A-26X-1. 


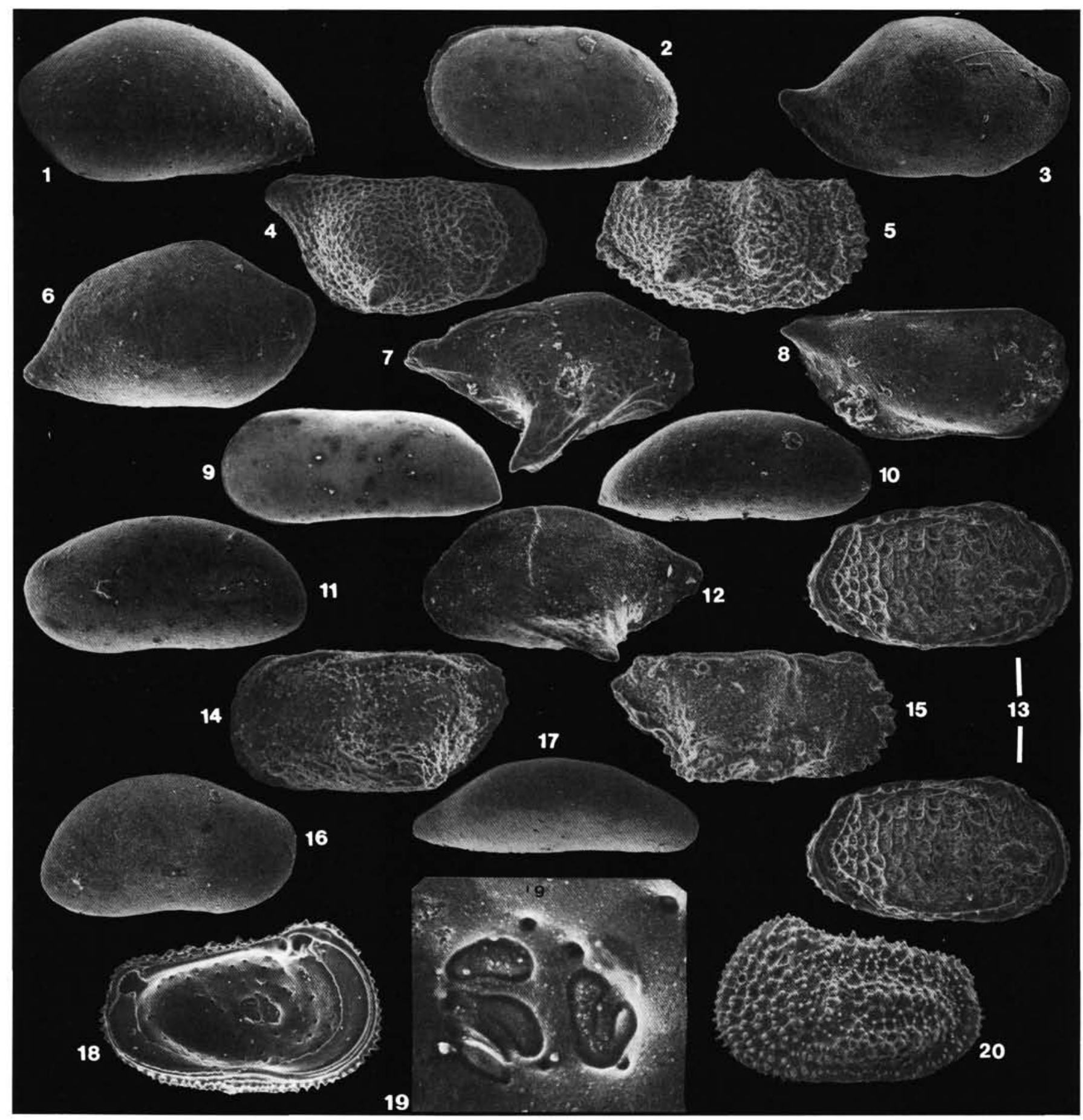

Plate 3. Neogene ostracodes of Hole 628A, probably deep-sea species. 1. Neonesidea? gerda, L.V. (larv.?) $\times 100$, Section 101-628A-12H-3. 2. Cytherella gr. consueta, L.V. ( $q$ ?) $\times 55$, Section 101-628A-15H-3. 3. Paranesidea? sp. 2, R.V. $\times 38$, Section 101-628A-24X-4. 4. Bythoceratina sp. 5, R.V. $\times 63$, Section 101-628A-3H-6. 5. Bythoceratina sp. 2, R.V., broken posteriorly, $\times 55$, Section 101-628A-4H-4. 6. Neonesidea? gerda, R.V. $\times 70$, Section 628A-2H-6. 7. Cytheropteron sp. 4, R.V. $\times 125$, Section 101-628A-6H-1. 8. Pseudocythere sp. 2 , R.V. ( 9 ?) $\times 95$, Section 101-628A-8H-7. 9. Krithe sp. 2, L.V. $\left(\sigma^{2}\right.$ ?) $\times 55$, Section 101-628A-15H-3. 10. Cardobairdia gr. asymmetrica, R.V. $\times 70$, Section 101-628A8H-6. 11. Bythocypris? sp., L.V. $\times 50$, Section 101-628A-12H-3. 12. Cytheropteron sp. 3, L.V. $\times 115$, Section 101-628A-8H-6. 13. Poseidonamicus pintoi, R.V. $\times 50$, Section 101-628A-4H-6. 14. Bythoceratina sp. 1, L.V. $\times 100$, Section 101-628A-8H-5. 15. Bythoceratina sp. 3, R.V. $\times 105$, Section 101-628-2H-6. 16. Bythocypris? sp., R.V. $\times 50$, Section 101-628A-3H-2. 17. Paracypris sp., R.V. $\times 30$, Section 101-628A-3H-2. 18-20. Henryhowella cf. evax, int. and ext. view of a L.V. $\times 65$, add. musc. $\times 200$, Section 101-628A-5X-1. 


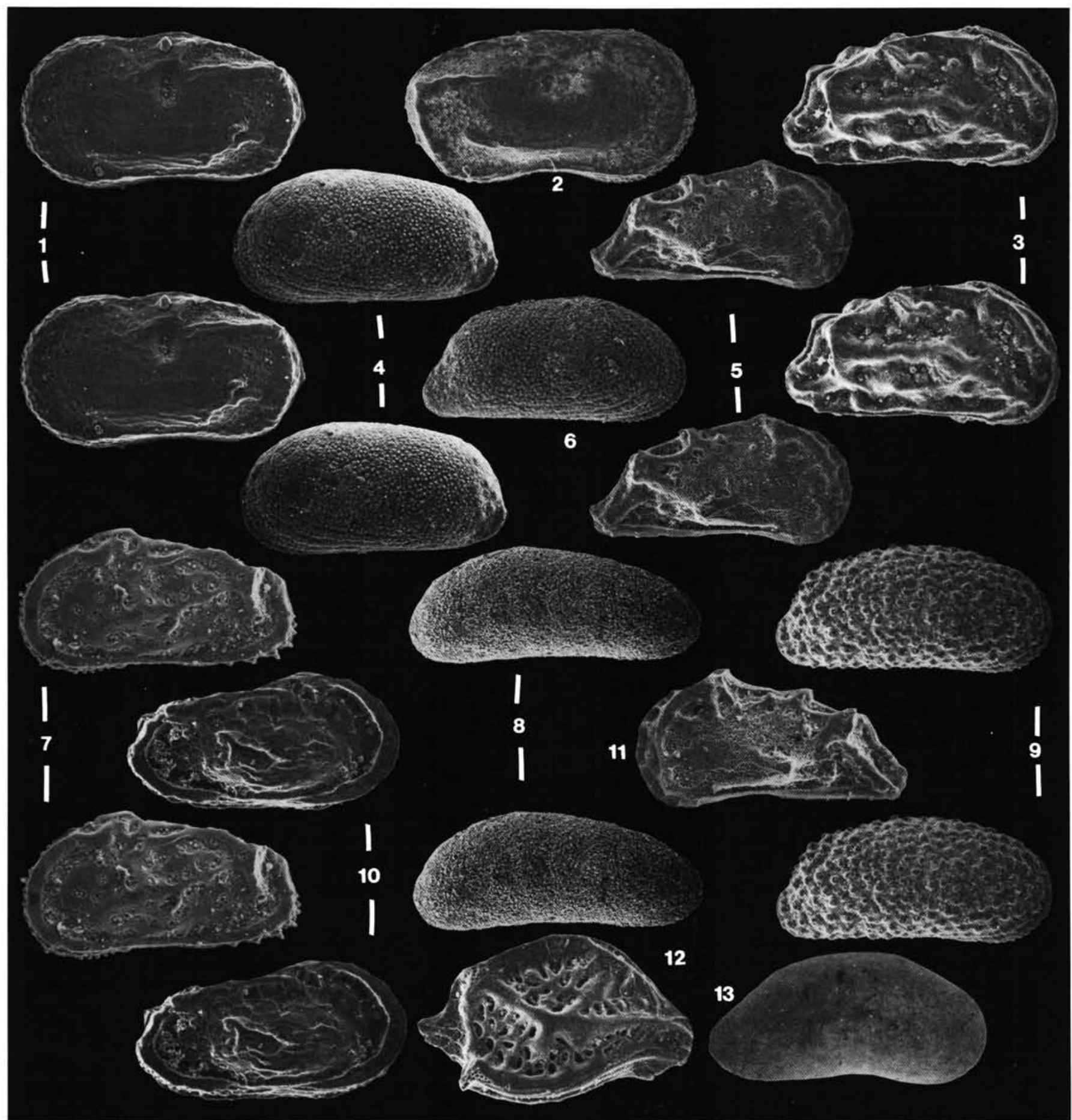

Plate 4. Neogene ostracodes of Hole 628A, probably neritic species (except 12 and 13). 1-2. Cytherelloidea sp., L.V. $\times 80$, Section 101-628A-2H-3 and R.V. $\times 75$, Section 101-628A-2H-6. 3. Caudites sp. 1., carapace $\times 80$, Section 101-628A-13H-3. 4 and 6. Hulingsina? sp. 1, L.V. $\times 80$, Section 101-628A-6H, CC and R.V. $\times 85$, Section 101-628A-6H-3. 5 and 11. Caudites sp. 2, R. and L.V. $\times 80$, Section 101-628A-6H, CC. 7. Neocaudites aff. maccagnoi, L.V. $\times 95$, Section 101-628A-11H-3. 8. Cushmanidea? sp., R.V. $\times 85$, Section 101-628A-2H-6. 9. Hulingsina cf. tuberculata, R.V. $\times 95$, Section 101-628A-6H, CC. 10. Occultocythereis? sp. 1, carapace $\times 90$, Section 101-628A-13H-3. 12. Kangarina abyssicola, R.V. $\times 130$, Section 101-628A-3H-5. 13. Bythocypris? sp., R.V. $\times 35$, Section 101-628A-2H-4. 


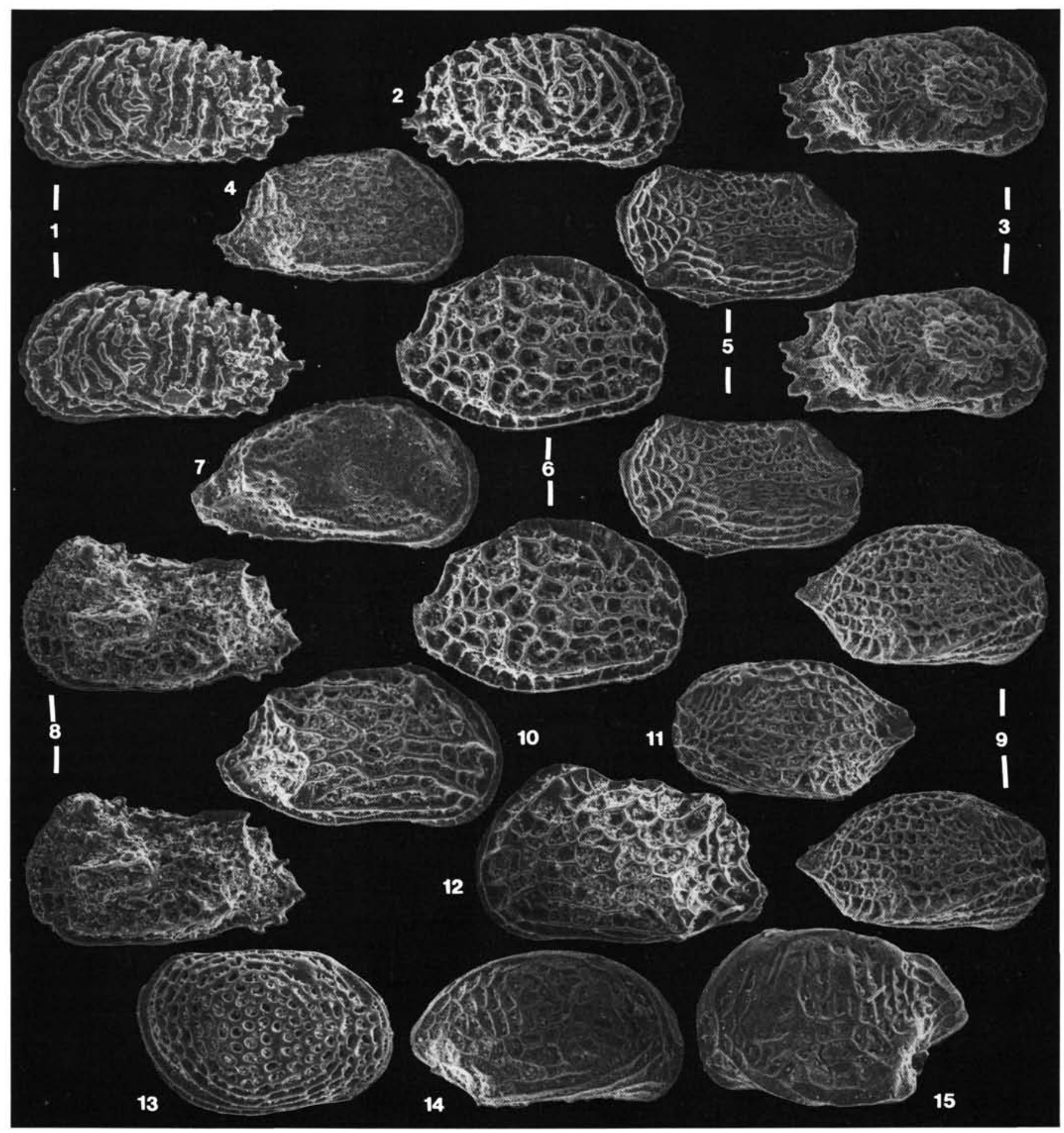

Plate 5. Neogene ostracodes of Hole 628A, probably neritic species. 1-2. Puriana cf. fissispinata, L. and R.V. $\times 80$, Section $101-628 \mathrm{~A}-3 \mathrm{H}-5$. 3. Puriana cf. convoluta, R.V. $\times 75$, Section 101-628A-5H-5. 4. Radimella sp. 2, R.V. $\times 80$, Section 101-628A-6H, CC. 5. Loxoconcha fischeri, R.V. $\times 70$, Section 101-628A-3H-5. 6. Malzella sp., R.V. $\times 80$, Section 101-628A-3H-5. 7. Gen. sp., R.V. $\times 90$, Section 101-628A-8H-5. 8. Jugosocythereis sp. 2, L.V. $\times 70$, Section 101-628A-4H-2. 9 and 11. Semicytherura sp. 1, R.V. $\times 100$ and L.V. $\times 90$, Sections $101-628$ A-6H-2 and $101-$ 628A-6H-1. 10 and 12. Radimella sp. 1, R. and L.V. $\times 92$, Section 101-628A-3H-3. 13. Loxoconcha sp. 1, R.V. $\times 80$, Section 101-628A-3H-5. 14-15. Gangamocytheridea cf. dictyon, R.V. $\left(\sigma^{\top}\right.$ ?) $\times 115$, Section 101-628A-13H-3 and L.V. $(q ?) \times 118$, Section $101-628 \mathrm{~A}-6 \mathrm{H}-2$. 


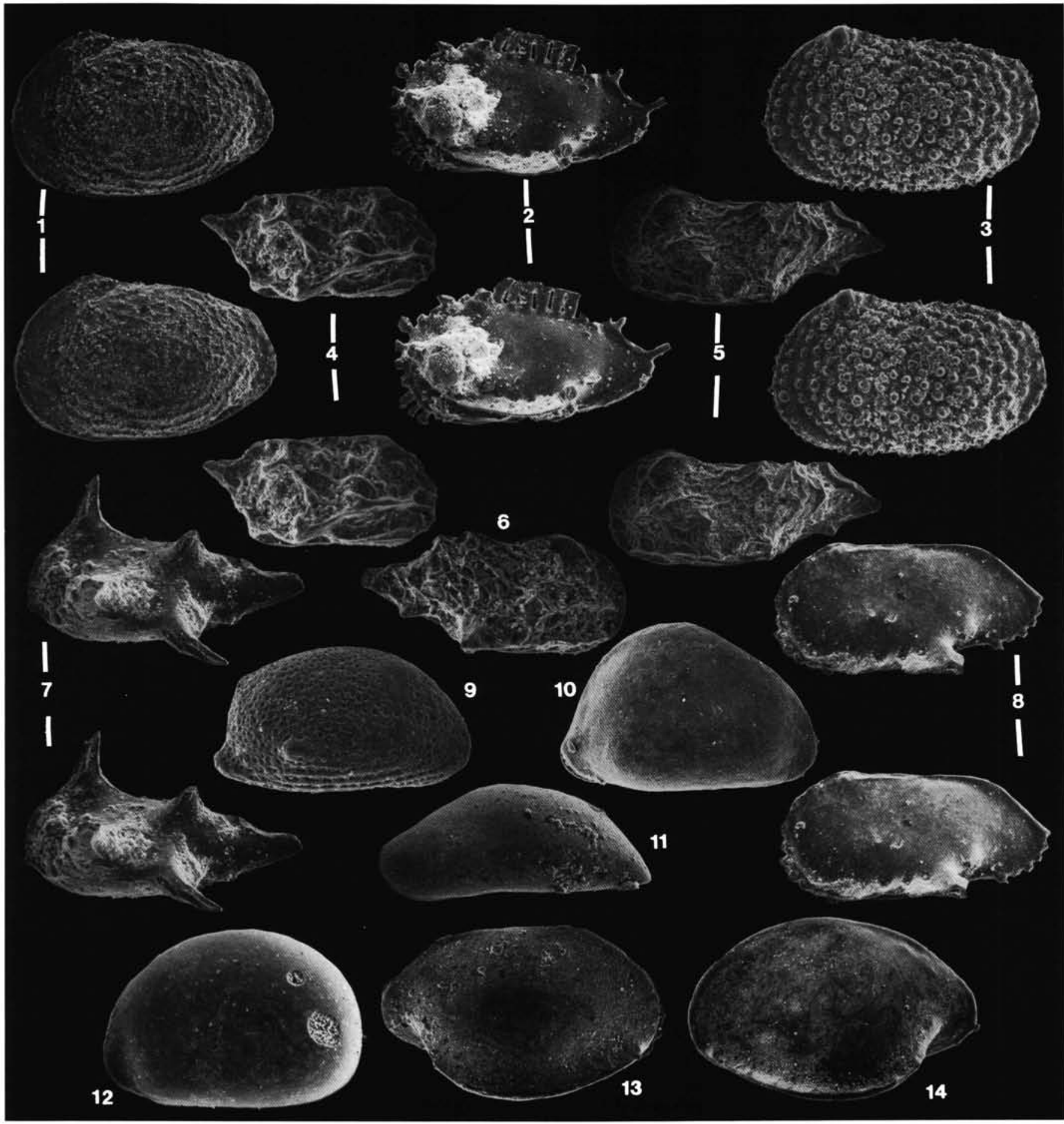

Plate 6. Neogene ostracodes of Hole 628A, neritic or deep-sea species. 1. Echinocythereis echinata, L.V. $\times 50$, Section 101-628A-3H-4. 2. Pterygocythereis sp. 2, L.V. $\times 55$, Section 101-628A-4H-2. 3. Echinocythereis margaritifera, L.V. $\times 47$, Section 101-628A-3H-2. 4. Paracytheridea? sp., R.V. $\times 125$, Section 101-628A-6H, CC. 5 and 6. Paracytheridea aff. byramensis, L.V. $(\sigma '$ ?) and R.V. ( $\$$ ?) $\times 75$, Section 101-628A6 H,CC. 7. Paracytheridea sp. 2, L.V. $\times 80$, Section 101-628A-8H-6. 8. Pterygocythereis sp. 1, L.V. $\times 53$, Section 101-628A-3H-3. 9. Ornatoleberis sp., R.V. $\times 80$, Section 101-628A-3H-5. $\quad$ 10. Uroleberis sp., R.V. $\times 93$, Section 101-628A-3H-1. 11. Paracypris? sp., L.V. $\times 55$, Section $101-$ 628A-13H-3. 12. Xestoleberis sp., V.D. $\times 90$, Section 101-628A-3H-5. 13 and 14. Brachycythere sp., R. and L.V. $\times 43$, Section 101-628A-2H-3. 